and thus enhanced the international prestige of Belgium. This year's prize has been awarded to Prof. Lemaitre for his. outstanding work on the systems of galaxies and on cosmic theory. His discoveries and theories have had a profound influence on astrophysical and physical thought throughout the world, especially in connexion with the theory of the expanding universe, which he originated. The presentation was made in the presence of the King of the Belgians.

\section{Native Problems in North Australia}

THE natives of Arnhem Land in North Australia are presenting an interesting problem to the Commonwealth Government. The methods usually adopted in dealing with disturbances among the natives are the old-time punitive police expedition or special missionary enterprise; quite recently a mixture of the two has been tried. As Prof. F. Wood Jones has pointed out, the former is apt to lead merely to massacre, and the latter must be admitted to have failed to effect any permanent solution of the problem. It is properly soluble only by rigorous segregation of the blacks from settlers, traders and the like (European and Asiatic), and by prolonged intimate study of them by highly trained anthropologists willing and able to live amongst them as members of their tribes. The University of Melbourne has made an admirable and practical move in offering to the Department of the Interior the services of an able and experienced research student to work amongst the Arnhem Land natives. To the great regret of all who are interested in these primitive peoples, the offer has been declined; but the last has not been heard of it. On scientific, no less than humanitarian, grounds a determined effort along sound modern lines should be made to resolve this long-neglected native problem. The establishment of a Commonwealth Department of Native Affairs would be a step in the right direction.

\section{Water Supplies in Great Britain}

IN reply to a question in the House of Commons on April 9 as to the present position in regard to water supplies in Great Britain, Mr. Ramsay MacDonald said: "The reserves of many water undertakers have fallen to a low level for this time of the year. The Government have been carefully watching the situation and, because of the continued absence of abundant rains, are satisfied that emergency measures must be taken. Therefore, in view of seriousness of the position, the Government propose to bring legislation before the House immediately." The Water Supplies (Exceptional Shortage Orders) Bill was accordingly presented to the House on April 10, whereby the Minister of Health, and the Secretary of State and the Department of Health for Scotland, would be authorised "to make orders, and to give directions with a view to meeting deficiencies in water supplies due to exceptional shortage of rain, and for purposes connected with the matters aforesaid". It will be remembered that the subject of water supply and regulation was discussed in
NATURE of November 11,1933, p. 725 , in an article dealing with a report of a committee of the British Association, when the institution of an inland water survey of Britain was urged as a necessary preliminary to efficient water administration. Reference was also made in that article to the presidential address to the Institution of Mechanical Engineers delivered by Mr. Alan Chorlton, M.P., in which he suggested the construction of a water 'grid' in Great Britain comparable with the electricity 'grid' recently completed.

\section{Pooling of Water Supplies}

Mr. Chorlton returned to the subject in a recent paper read before the Royal Society of Arts ( $J$. Roy. Soc. Arts, Feb. 23, 1934), in which he directs attention to the policy of Great Britain, which has allowed water supply to remain in the hands of local authorities without any national plan devised in the interests of the population as a whole. As a result, there are 1,100 separate water undertakings in the country with a mosaic of disconnected entities and interlocking boundaries. Urban areas are best served, but many rural areas require adequate provision. A hydrogeological survey is needed before plans on a large scale can be matured. Furthermore, some pooling of supplies is essential because of the vagaries of rainfall within any given year, and lastly, special storage reservoirs should be constructed to serve abnormal demands in dry seasons. These might be in the Thames valley, for the south generally; in south Lincolnshire for the Ouse flood waters; and in the Lake District to serve the industrial areas of Lancashire. Such undertakings would, according to Mr. Chorlton, have many advantages in providing a certainty of good water in all areas, and a possibility of encouraging increased use of water without alarm of shortage, while the expenditure on labour would decrease unemployment for some years to come.

\section{Australian Support for Empire Agricultural Research}

Satisfaction will be felt at the decision of the Commonwealth Government to adopt the recommendation of the Executive Council of the Imperial Agricultural Bureaux that financial support be given to certain research organisations in Great Britain formerly assisted in part by the Empire Marketing Board. It is true that the sum involved is not very considerable : $£ 800$ per annum to the Entomological Laboratory at Farnham Royal, $£ 500$ to the Station at Slough dealing with insect infestation of stored products, and $\mathfrak{1 4 , 5 0 0}$ to the Low Temperature Research Station at Cambridge; a total of $£ 5,800$ per annum. The point of importance, however, is that the Australian decision is an indication of the growing feeling there that teamwork in agricultural research is not merely desirable in the interests of the various members of the Empire, but also is essential if full advantage is to be taken of the limited total resources available for scientific work. The Empire Marketing Board did much to foster this spirit, the value of which is clearly recognised in the outlying dominions. 